\section{BRAZIULIAN JOURNAL}

OF MEDICAL AND BIOLOGICAL RESFARCH

www.bjournal.com.br
ISSN 0100-879X

Volume 43 (10) 914-1009 October 2010

BIOMEDICAL SCIENCES

AND

CLINICAL INVESTIGATION

Braz J Med Biol Res, October 2010, Volume 43(10) 957-963

doi: 10.1590/S0100-879X2010007500095

Noncrystalline uric acid inhibits proteoglycan and glycosaminoglycan synthesis in distal tubular epithelialcells (MDCK)

F.T. Borges, M.A. Dalboni, Y.M. Michelacci and N. Schor

The Brazilian Journal of Medical and Biological Research is partially financed by
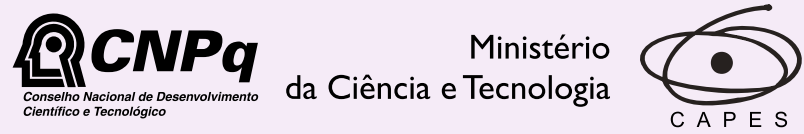

Ministério da Educação

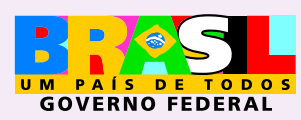

DFAPESP

Institutional Sponsors
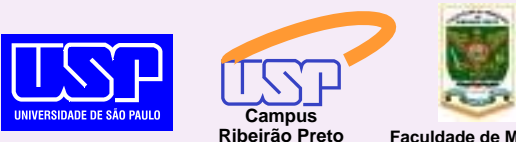

Ф SHIMADZU

GE Healthcare
Hotsite of proteomics metabolomics developped by: 


\title{
Noncrystalline uric acid inhibits proteoglycan and glycosaminoglycan synthesis in distal tubular epithelial cells (MDCK)
}

\author{
F.T. Borges ${ }^{1}$, M.A. Dalboni ${ }^{1}$, Y.M. Michelacci ${ }^{2}$ and N. Schor ${ }^{1}$ \\ ${ }^{1}$ Disciplina de Nefrologia, Departamento de Medicina, ${ }^{2}$ Disciplina de Biologia Molecular, \\ Departamento de Bioquímica, Universidade Federal de São Paulo, São Paulo, SP, Brasil
}

\begin{abstract}
Hyperuricemia is associated with renal stones, not only consisting of uric acid (UrAc) but also of calcium oxalate (CaOx). Glycosaminoglycans (GAGs) are well-known inhibitors of growth and aggregation of CaOx crystals. We analyzed the effect of noncrystalline UrAc on GAG synthesis in tubular distal cells. MDCK (Madin-Darby canine kidney) cells were exposed to noncrystalline UrAc $(80 \mu \mathrm{g} / \mathrm{mL})$ for $24 \mathrm{~h}$. GAGs were labeled metabolically and characterized by agarose gel electrophoresis. The expression of proteoglycans and cyclooxygenase 2 (COX-2) was assessed by real-time PCR. Necrosis, apoptosis and prostaglandin E2 (PGE2) were determined by acridine orange, HOESCHT 33346, and ELISA, respectively. CaOx crystal endocytosis was evaluated by flow cytometry. Noncrystalline UrAc significantly decreased the synthesis and secretion of heparan sulfate into the culture medium (UrAc: $2127 \pm 377$; control: $4447 \pm 730 \mathrm{cpm}$ ) and decreased the expression of perlecan core protein (UrAc: $0.61 \pm 0.13$; control: $1.07 \pm 0.16$ arbitrary units), but not versican. Noncrystalline UrAc did not induce necrosis or apoptosis, but significantly increased COX-2 and PGE2 production. The effects of noncrystalline UrAc on GAG synthesis could not be attributed to inflammatory actions because lipopolysaccharide, as the positive control, did not have the same effect. CaOx was significantly endocytosed by MDCK cells, but this endocytosis was inhibited by exposure to noncrystalline UrAc (control: 674.6 \pm 4.6 , CaOx: 724.2 \pm 4.2 , and UrAc + $\mathrm{CaOx}$ : $688.6 \pm 5.4$ geometric mean), perhaps allowing interaction with $\mathrm{CaOx}$ crystals. Our results indicate that UrAc decreases GAG synthesis in MDCK cells and this effect could be related to the formation of UrAc and CaOx stones.
\end{abstract}

Key words: Noncrystalline uric acid; Glycosaminoglycan; MDCK; Lipopolysaccharide; Apoptosis; Proteoglycan

\section{Introduction}

Kidney stones are composed of a mixture of inorganic and organic components, as well as proteins. Crystallization (and subsequently lithogenesis) may occur from different solutes in urine. Calcareous stones are the most common $(80 \%)$, while uric acid (UrAc) stones represent only $5-10 \%$, followed by cystine, struvite, and ammonium acid urate stones (1-3).

UrAc stones can result from either hyperuricosuria, acidic urine, or both $(4,5)$. At low urine $\mathrm{pH}$, UrAc can induce heterogeneous nucleation of calcium oxalate ( $\mathrm{CaOx})$. This mechanism constitutes the basis for potential hyperuricosuric calcium urolithiasis. At high urine $\mathrm{pH}$, solubility of UrAc increases (noncrystalline UrAc). Once considered as inert product and the main serum antioxidant, soluble UrAc has proinflammatory effects that can contribute to the development of UrAc stones.
The urine is normally supersaturated with solutes, such as $\mathrm{CaOx}$, calcium phosphate, sodium urate, and UrAc, among others. In non-stone formers, the supersaturation is maintained, without precipitation, as a result of urinary inhibitors such as magnesium, citrate, pyrophosphate, Tamm-Horsfall protein, and glycosaminoglycans (GAGs). Some inhibitors are able to inhibit nucleation, while others inhibit crystal growth and aggregation $(6,7)$.

In humans, the main urinary GAGs are chondroitin sulfate (CS) and heparan sulfate (HS), with small amounts of dermatan sulfate and trace amounts of hyaluronic acid and keratan sulfate (8). It has been shown that GAGs inhibit the growth and aggregation of $\mathrm{CaOx}$ crystals in vitro (9). Our laboratory has shown that stone-forming subjects, both children and adults, have lower concentrations of urinary GAG (8). There is evidence suggesting that urinary CS

Correspondence: N. Schor, Rua Pedro de Toledo, 740, 2o andar, 04023-900 São Paulo, SP, Brasil. Fax: +55-11-5573-9652.

E-mail: nestor@nefro.epm.br

Received February 8, 2010. Accepted August 19, 2010. Available online September 24, 2010. Published October $18,2010$. 
is of systemic origin (10), while urinary HS and, possibly, dermatan sulfate could be of systemic origin or come from the kidney and/or urinary tract.

HS is the main kidney GAG, occurring both as a cell surface proteoglycan (PG) of the syndecan and glypican families, and as perlecan, the main basement membrane proteoglycan (11). Furthermore, the expression of the core protein of four small PG - decorin, biglycan, fibromodulin, and lumican - has been observed in the renal interstitium, with accumulation around tubules. Low expression of these core proteins has also been observed in the mesangial matrix (12). Increased expression of dermatan sulfate PG has also been shown in experimental models of chronic renal failure (13) and diabetes mellitus (14).

In contrast, increased expression of syndecan-1, a cell surface HS-PG, has been demonstrated in rat kidney with $\mathrm{CaOx}$ nephrolithiasis (15). The increased expression of syndecan-1 and HS in a cell line derived from Madin-Darby canine kidney (MDCK) cells led to a decrease in $\mathrm{CaOx}$ attachment to these cells (16), suggesting a protective role for this $P G$ in $\mathrm{CaOx}$ nephrolithiasis. MDCK, a cell line derived from the distal tubular epithelium, expresses many PGs, also found in the kidney cortex as HS-PG perlecan, agrin, and collagen XVIII, as well as the CS-PG biglycan, bamacan, and versican (17). These PGs are also associated with mammalian kidney tubules in vivo.

Exposure of MDCK type I cells to UrAc crystals and soluble UrAc was associated with increased monohydrate $\mathrm{CaOx}$ crystal adhesion and this binding was inhibited by prostaglandin E2 (PGE2) supplementation and delayed by blockade of prostaglandin production (18). Soluble UrAc also has proinflammatory and deleterious effects on endothelial, vascular smooth muscle and proximal tubular cells such as proliferation, activation of mitogen-activated protein kinases (MAPK), chemokines (monocyte chemoattractant protein-1), and the inflammatory enzymes cyclooxygenase 2 (COX-2) and prostaglandins (19).

The objective of the present study was to determine the effects of noncrystalline UrAc on the synthesis of GAGs, on inflammation and on the endocytosis of $\mathrm{CaOx}$ crystals in MDCK cells.

\section{Material and Methods}

\section{Cell culture}

Madin-Darby canine kidney cells, which are derived from distal tubular epithelial cells, were obtained from the American Type Culture Collection (ATCC, USA). They were grown in Dulbecco's modified Eagle's medium (DMEM, Sigma-Aldrich, USA) containing 5\% fetal bovine serum (FBS, Gibco, Life Technologies, USA), $24 \mathrm{mM} \mathrm{NaHCO}_{3}$, $10 \mathrm{mM}$ HEPES, and 10,000 U/L penicillin/streptomycin (Gibco). The cultures were incubated at $37^{\circ} \mathrm{C}$ in a humidified atmosphere containing $5 \%$ carbon dioxide.

At the semi-confluence stage, cells were detached from the plastic flasks with trypsin (0.05\%; Cultilab, Brazil), centrifuged, resuspended in DMEM and subcultured in $25-\mathrm{cm}^{2}$ plastic culture flasks for the experimental procedures.

\section{Preparation of noncrystalline UrAc}

UrAc $(0.01 \mathrm{~g})$, obtained commercially (Merck EGaA, Germany), was added to $100 \mathrm{~mL}$ ethanol $(100 \mu \mathrm{g} / \mathrm{mL})$ with continuous stirring for $24 \mathrm{~h}$. UrAc crystals were dried, sterilized in ethylene oxide or steam autoclaved, and suspended in culture medium without FBS $(100 \mathrm{~mL})$. The suspension was sonicated for $15 \mathrm{~min}$ to dissolve UrAc crystals and then passed through a $22-\mu \mathrm{m}$ pore filter to sterilize it. After filtration, the concentration of UrAc was quantified and, when necessary, was increased to correct it and filtered again.

\section{Preparation of $\mathrm{CaOx}$ crystals}

Solutions of calcium chloride $(0.4 \mathrm{M}, 100 \mathrm{~mL})$ and dipotassium oxalate $(0.4 \mathrm{M}, 100 \mathrm{~mL}$; Merck EGaA) were added to $300 \mathrm{~mL}$ distilled deionized water at a constant rate of 1 $\mathrm{mL} / \mathrm{min}$, for $2 \mathrm{~h}$. This suspension was continuously stirred for $5 \mathrm{~h}$ at $75^{\circ} \mathrm{C}$, and then washed with deionized water to remove excess $\mathrm{KCl}$. The remaining saturated solution was stored at $37^{\circ} \mathrm{C}$ for 15 days to allow CaOx crystallization. The resulting $\mathrm{CaOx}$ crystals $(0.1 \mathrm{~g})$ were sterilized in ethylene oxide or in a steam autoclave, and suspended in culture medium without FBS $(100 \mathrm{~mL})$. The suspension $(1000 \mu \mathrm{g} / \mathrm{mL})$ was sonicated for $15 \mathrm{~min}$ to reduce particles to a uniform size.

\section{Exposure of MDCK cells to noncrystalline UrAc and CaOx crystals}

Hyperuricemia is characterized by serum UrAc concentrations above $70 \mu \mathrm{g} / \mathrm{mL}$ for men and $60 \mu \mathrm{g} / \mathrm{mL}$ for women and the concentration of $80 \mu \mathrm{g} / \mathrm{mL}$ was chosen for the experiments.

Prior to the experiments, cells were transferred to a six-well plate $\left(1 \times 10^{6}\right.$ cells/well) or to culture flasks and maintained under the culture conditions for 3 days. At confluence, MDCK cells were exposed for $24 \mathrm{~h}$ to DMEM (without FBS, control), DMEM containing noncrystalline UrAc $(80 \mu \mathrm{g} / \mathrm{mL})$ or lipopolysaccharide (LPS) $(100 \mu \mathrm{g} / \mathrm{mL})$ or CaOx $(100 \mu \mathrm{g} / \mathrm{mL})$.

\section{Noncrystalline UrAc and $\mathrm{CaOx}$ crystal endocytosis}

$\mathrm{CaOx}$ and UrAc endocytosis was determined by flow cytometry. Briefly, the flow cytometer detects how the cell interacts with a focused laser beam in terms of how the cell scatters the incident light and emits fluorescence. In forward scatter, light is diffracted at low angles, generally proportional to cell size and the side scatter light is reflected at high angles, proportional to cell granularity and complexity and detected at $90^{\circ}$ to the incident light axis (20).

Cultures of MDCK cells were exposed to $\mathrm{CaOx}(100 \mu \mathrm{g} /$ $\mathrm{mL})$ and UrAc $(80 \mu \mathrm{g} / \mathrm{mL})$ as described above. After 24-h incubation, the cells were washed with PBS and incubated 
with the trypsin-EDTA (0.25\%) solution (Cultilab, Brazil). This procedure yields only cells containing internalized or strongly adherent crystals. Cell suspensions were transferred to conical fluorescence-activated cell sorter (FACS) tubes and immediately analyzed with a FACScan flow cytometer (FacsCalibur analyzer; Becton-Dickinson Immunocytometry Systems, USA). Data were acquired for up to $5 \times 10^{3}$ cells from each sample. Light intensity histograms were constructed for each experimental situation, and the geometric mean of light intensity for the cell population was determined. CaOx crystals were excluded from analysis using a gated analysis method based on forward light scatter and side scatter. MDCK cell complexity (granularity) was considered as a control parameter and compared with cellular complexity after $\mathrm{CaOx}$ or UrAc exposition.

\section{Glycosaminoglycan extraction and quantification}

$\operatorname{MDCK}\left(10^{6}\right.$ cells $)$ were treated with noncrystalline UrAc $(80 \mu \mathrm{g} / \mathrm{mL})$ and LPS $(100 \mu \mathrm{g} / \mathrm{mL})$. At the same time, $\mathrm{H}_{2}{ }^{35} \mathrm{SO}_{4}$ $(100 \mu \mathrm{Ci} / \mathrm{mL})$ was also added to the culture medium for the metabolic labeling of GAGs. After $24-\mathrm{h}$ incubation at $37^{\circ} \mathrm{C}$, the medium and cell extract were obtained as described (21). Briefly, the culture medium was collected (medium fraction) and, after three PBS washes, the cells were incubated with 3.5 M urea in $50 \mathrm{mM}$ Tris- $\mathrm{HCl}, \mathrm{pH} 7.4$, and scraped from the flask surface and transferred to a centrifuge tube.

CS and HS (100 $\mu \mathrm{g}$ each) were added, as carriers, to each fraction. After the addition of 3 volumes of ethanol, the mixtures were maintained at $-20^{\circ} \mathrm{C}$ for $24 \mathrm{~h}$. The precipitates formed were collected by centrifugation and vacuum dried.

For the extraction of GAG, the precipitates formed in each fraction were resuspended in $100 \mu \mathrm{L}$ phosphatecysteine buffer (60 mM, pH 6.5) containing EDTA (20 mM) and $100 \mu \mathrm{g} / \mathrm{mL}$ papain (Sigma-Aldrich) and incubated at $50^{\circ} \mathrm{C}$ overnight.

The compounds thus obtained were analyzed by a combination of agarose electrophoresis and enzymatic degradation with specific mucopolysaccharidases $(22,23)$.

The ${ }^{35}$ S-sulfate-labeled compounds were visualized by exposure of the agarose gel slabs (after fixation, drying, and staining) to a Packard Cyclone ${ }^{\mathrm{TM}}$ Storage Phosphor System (Packard Instrument, USA) for 1 day. For quantification, they were scraped off the agarose gels and counted with a Beckman 6800 liquid scintillation spectrophotometer (Beckman Coulter Inc., USA) using the Ultima Gold LSC-Cocktail (Perkin Elmer, USA) (24) and reported as cpm/106 cells. The quantitative results were corrected for ${ }^{35} \mathrm{~S}$-decay.

\section{RNA isolation, reverse transcription and quantitative real-time PCR}

Total RNA was purified from MDCK cells by the phenol and guanidine isothyocyanate-cesium chloride method using an appropriate kit (Trizol, Life Technologies, USA). Two micrograms of total RNA was treated with DNase (RQ1 RNase - Free DNase, Promega, USA) to prevent genomic DNA contamination. The RNA pellet was resuspended in RNase-free water, and reverse transcribed into cDNA by the addition of $0.5 \mathrm{mg} / \mathrm{mL}$ oligo d(T), $10 \mathrm{mM} \mathrm{DTT}, 0.5 \mathrm{mM}$ dNTPs (GE Healthcare, UK), and $200 \mathrm{U}$ reverse transcriptase enzyme (SuperScript RT, Life Technologies).

Real-time amplification was performed with a GeneAmp 5700 Sequence Detection System SDS (ABI Prism 7700, Applied Biosystems, Life Technologies, USA). Real-time $\mathrm{PCR}$ product accumulation was monitored using the intercalating dye, SYBR Green I (Applied Biosystems, Life Technologies), which exhibits a higher fluorescence upon binding to double-stranded DNA.

Relative gene expression was calculated using the conditions of the early stages of PCR, when amplification was logarithmic and, thus, could be correlated with the initial copy number of gene transcripts. The reactions were cycled 40 times under the conditions previously determined by conventional PCR. Fluorescence for each cycle was quantitatively analyzed. At the end of the PCR, the temperature was increased from $60^{\circ}$ to $95^{\circ} \mathrm{C}$ at a rate of $2^{\circ} \mathrm{C} / \mathrm{min}$, and fluorescence was measured every $15 \mathrm{~s}$ to construct the melting curve. A nontemplate control was run with each assay.

Gene sequences were obtained from GenBank and PCR was performed with specific primers for COX-2, perlecan and $\beta$-actin. Primers were designed with the Primer Express software v2.0 from Applied Biosystems (Table 1). Results of 8 independent experiments per group are reported as relative expression normalized with the $\beta$-actin housekeeping gene, used as an endogenous control.

Table 1. Primer sequences, product size and annealing temperature for $\beta$-actin, proteoglycans and cyclooxygenase-2 (COX-2) genes.

\begin{tabular}{llcc}
\hline Gene & Sequence $\left(5^{\prime}\right.$ to $\left.3^{\prime}\right)$ & Product size (bp) & Annealing temperature \\
\hline COX-2 & AAG TCC CTG AGC ATC TAC GGT TT & 98 & $55^{\circ} \mathrm{C}$ \\
NM000963.2 & GTT GTG TTC CCT CAG CCA GAT T & & \\
Perlecan & TTT CGA GAG GTG TCC GAG GCT & 256 & $58^{\circ} \mathrm{C}$ \\
NM005529.5 & TTA TCT TGG GAA CTG GGG CAC & & \\
$\beta$-actin & CCT CTA TGC CAA CAC AGT GC & 191 & $56.9^{\circ} \mathrm{C}$ \\
EF156276.1 & ACA TCT GCT GGA AGG TGG AC & & \\
\hline
\end{tabular}




\section{Real-time data analysis}

The cycle threshold $(\mathrm{Ct})$ values were subtracted from the $\mathrm{Ct}$ value for each gene (to give $\Delta \mathrm{Ct}$ values). These values were used for statistical comparisons. For graphic representation, the fold variation was then determined using the $2^{-(\Delta \Delta C t)}$ method according to published protocols (25) and manufacturer recommendations. Fold variation was calculated by determining the difference in $\Delta \mathrm{Ct}$ values between a chosen reference and test sample ( $\Delta \Delta \mathrm{Ct}$ value), and applying the $2^{-(\Delta \Delta C t)}$ formula.

\section{Cell viability experiments}

Necrotic and apoptotic cells were identified using acrydine orange/ethidium bromide (Sigma-Aldrich) and HOESCHT 33342 (Bisbenzimide Hoe 33342 (2'-[4-ethoxyphenyl]-5-[4-methyl-1-piperazinyl]-2,5'-bi-1Hbenzimidazole); Sigma-Aldrich) dyes, respectively. MDCK
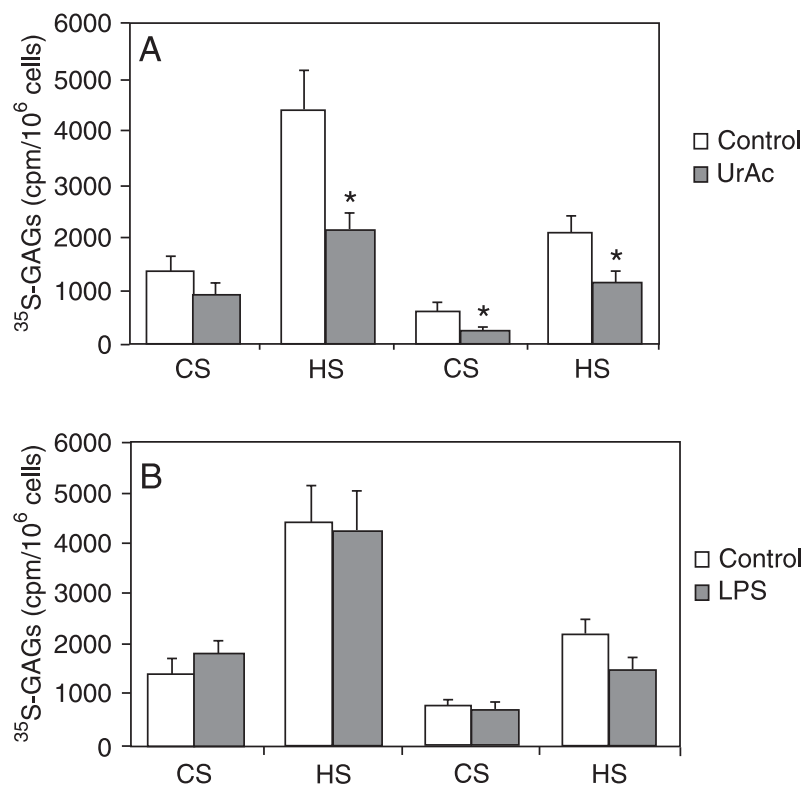

Figure 1. Effect of uric acid (UrAc) and lipopolysaccharide (LPS) on the synthesis of ${ }^{35} \mathrm{~S}$-chondroitin sulfate (CS) and ${ }^{35} \mathrm{~S}$-heparan sulfate (HS) in MDCK cells. MDCK cells exposed to DMEM without FBS (control), UrAc $(80 \mu \mathrm{g} / \mathrm{mL})(A)$ or LPS, Escherichia coli 0111:B4 (B) were incubated with $\mathrm{H}_{2}{ }^{35} \mathrm{SO}_{4}$. After $24 \mathrm{~h}$, the culture medium ( $1 \mathrm{~mL}$ ) was collected and labeled "medium fraction". The cells were treated with $3.5 \mathrm{M}$ urea in $50 \mathrm{mM}$ Tris- $\mathrm{HCl}, \mathrm{pH} 7.4$, and scraped from the flask surface. The solution was labeled "cell extract". After addition of 3 volumes of ethanol, the mixtures were maintained at $-20^{\circ} \mathrm{C}$ for $24 \mathrm{~h}$, then centrifuged, vacuum dried, and the precipitates resuspended in $100 \mu \mathrm{L} 60 \mathrm{mM}$ phosphatecysteine buffer, $\mathrm{pH} 6.5$, containing $20 \mathrm{mM}$ EDTA and $100 \mu \mathrm{g} /$ $\mathrm{mL}$ papain at $50^{\circ} \mathrm{C}$ for $24 \mathrm{~h}$. Aliquots of culture medium and cell extract of each experimental situation were submitted to agarose gel electrophoresis. The ${ }^{35} \mathrm{~S}-\mathrm{GAG}$ s were identified and quantified. Results are reported as means \pm SEM ${ }^{35}$ S-glycosaminoglycans ( ${ }^{35} \mathrm{~S}-\mathrm{GAGs} \mathrm{cpm} / 10^{6}$ cells). Each assay was repeated at least six times. ${ }^{*} \mathrm{P}<0.05$ compared to control (Student $t$-test). suspensions were centrifuged, resuspended in PBS and incubated with acrydine orange/ethidium bromide solution for 5-15 min. Cells were then observed under the light microscope. Ethidium bromide stains all cells green, while acrydine orange is excluded from viable cells. HOESCHT 33342 stains the chromatin. Blue cells were considered to be non-apoptotic, and cells with condensed chromatin were considered to be apoptotic. At least 100 cells per culture were counted, and the results are reported as percent necrotic or apoptotic cells.

\section{PGE2 production}

The concentrations of PGE2 were assessed in cell cultures treated with noncrystalline UrAc alone or associated with LPS through commercial competitive ELISAs (Cayman Chemical, USA). All assays were performed according to manufacturer protocols. The absorbance of each sample was read with the Ultra Microplate Reader EL808 (Bio-Tek Instruments, USA) and is reported as picograms per milliliter.

\section{Statistical analysis}

Data are reported as means \pm SEM. Experimental and control groups were compared by the Student $t$-test. The level of significance was set at $5 \%(P<0.05)$ in all analyses.

\section{Results}

The MDCK cell line synthesized a mixture of CS (32.5\%) and HS (67.5\%). Most of the GAGs were secreted into the culture medium, while smaller amounts were observed in the cell extract (Figure 1A). Noncrystalline UrAc $(80 \mu \mathrm{g} /$ $\mathrm{mL}$ ) significantly decreased the HS concentration of both the culture medium (2127 $\pm 377 \mathrm{cpm})$ and cell extract $(1131 \pm 273 \mathrm{cpm})$ compared to control culture medium $(4447 \pm 730 \mathrm{cpm})$ and cell extract $(2148 \pm 307 \mathrm{cpm})$, and also decreased CS concentration in the cell extract (285 $\pm 73 \mathrm{cpm}$ ) compared to control cell extract (669 \pm 143$)$. At higher concentrations of UrAc $(200 \mu \mathrm{g} / \mathrm{mL})$, there was no decrease in GAG synthesis. LPS, used as a positive control for inflammation, had no effect on CS or HS synthesis or secretion (Figure 1B).

Figure 2 shows the effect of noncrystalline UrAc on the expression of perlecan core protein. UrAc $(80 \mu \mathrm{g} / \mathrm{mL})$ decreased perlecan expression in MDCK $(0.61 \pm 0.13$ arbitrary units, $\mathrm{AU}$ ) compared to the control situation (1.07 \pm $0.16 \mathrm{AU})$ but the higher concentration $(200 \mu \mathrm{g} / \mathrm{mL})$ did not show the same effect. These results agree with the findings on HS synthesis shown in Figure 1. In contrast, UrAc had no significant effect on the expression of versican core protein (data not shown).

There was no increase in necrotic (UrAc: $8.7 \pm 1.7 \%$ vs control: $6.1 \pm 1.9 \%$ ) or apoptotic (UrAc: $6.1 \pm 2.0 \%$ vs control: $6.8 \pm 1.8 \%$ ) rate after exposure to UrAc. Only very 
high concentrations of UrAc $(400 \mu \mathrm{g} / \mathrm{mL})$ induced cell death by apoptosis in this cell line (data not shown).

In gout, UrAc accumulation is associated with inflammation. On the other hand, in the renal system, the mechanisms described for UrAc effects on proximal epithelial tubular cells include NF-kB, protein kinase C, MAPK and cPLA2 (19). In the present study, we tested the hypothesis that COX-2 activation and its synthesis product prostaglandin could be related to the effect of noncrystalline UrAc in these cells. Figure 3 shows the effect of UrAc on COX-2 expression and PGE2 synthesis in MDCK cells. Noncrystalline UrAc $(80 \mu \mathrm{g} / \mathrm{mL})$ significantly increased COX-2 expression in these cells $(5.63 \pm 1.88 \mathrm{AU})$ compared to control $(0.88 \pm$ $0.22 \mathrm{AU}$; Figure 3A).

UrAc significantly increased PGE2 production (439.5 $\pm 2.1 \mathrm{pg} / \mathrm{mL}$ ) compared to control $(178.4 \pm 10.5 \mathrm{pg} / \mathrm{mL}$ ) in this cell line (Figure 3B). This result agrees with COX-2 expression induced by UrAc in this cell line.

The endocytosis of UrAc and CaOx crystals in MDCK cells was assessed by flow cytometry. $\mathrm{CaOx}$ (724.2 \pm 4.2 geometric mean), but not UrAc $(80 \mu \mathrm{g} / \mathrm{mL})$ increased MDCK cellular complexity when compared to the control situation (674.6 \pm 4.6 geometric mean). After exposure to UrAc, there was a small but significant decrease in the endocytosis of $\mathrm{CaOx}(688.6 \pm 5.4$ geometric mean) in these cells.

\section{Discussion}

The present study demonstrates that noncrystalline UrAc significantly decreases GAG and perlecan synthesis in Madin-Darby canine kidney cells. These effects could not be attributed to inflammatory induction or to the cell damage induced by UrAc. Furthermore, UrAc decreased

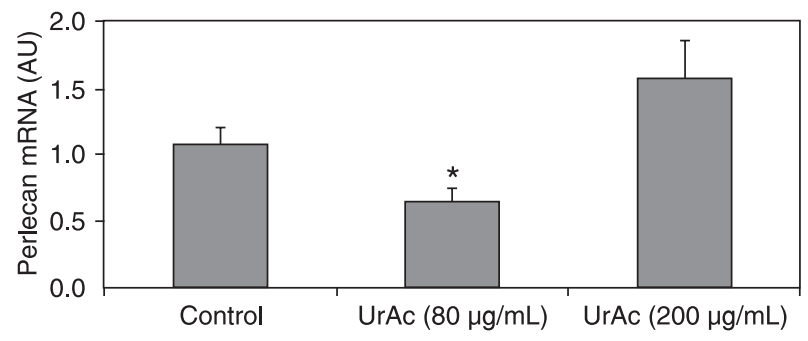

Figure 2. Effect of uric acid (UrAc) on perlecan mRNA expression in MDCK cells. Semi-confluent MDCK cells were treated with 80 or $200 \mu \mathrm{g} / \mathrm{mL}$ UrAc for $24 \mathrm{~h}$. Total RNA was purified and reverse transcribed into cDNA. PCR was performed with primers for perlecan. Real-time PCR product accumulation was monitored using the intercalating dye, SYBR Green I. The reactions were cycled 40 times under the conditions described in the text. Fluorescence for each cycle was quantitatively analyzed and relative gene expression was calculated. A nontemplate control was run with each assay. Results of 8 experiments per group are reported as relative expression normalized with the $\beta$-actin housekeeping gene. Data are reported as means \pm SEM arbitrary units (AU). ${ }^{*} \mathrm{P}<0.05$ compared to control (Student $t$-test).
$\mathrm{CaOx}$ crystal endocytosis, which could increase the $\mathrm{CaOx}$ availability in urine, and thus promote the aggregation or nucleation of $\mathrm{CaOx}$ crystals.

Hyperuricemia is associated with the development of
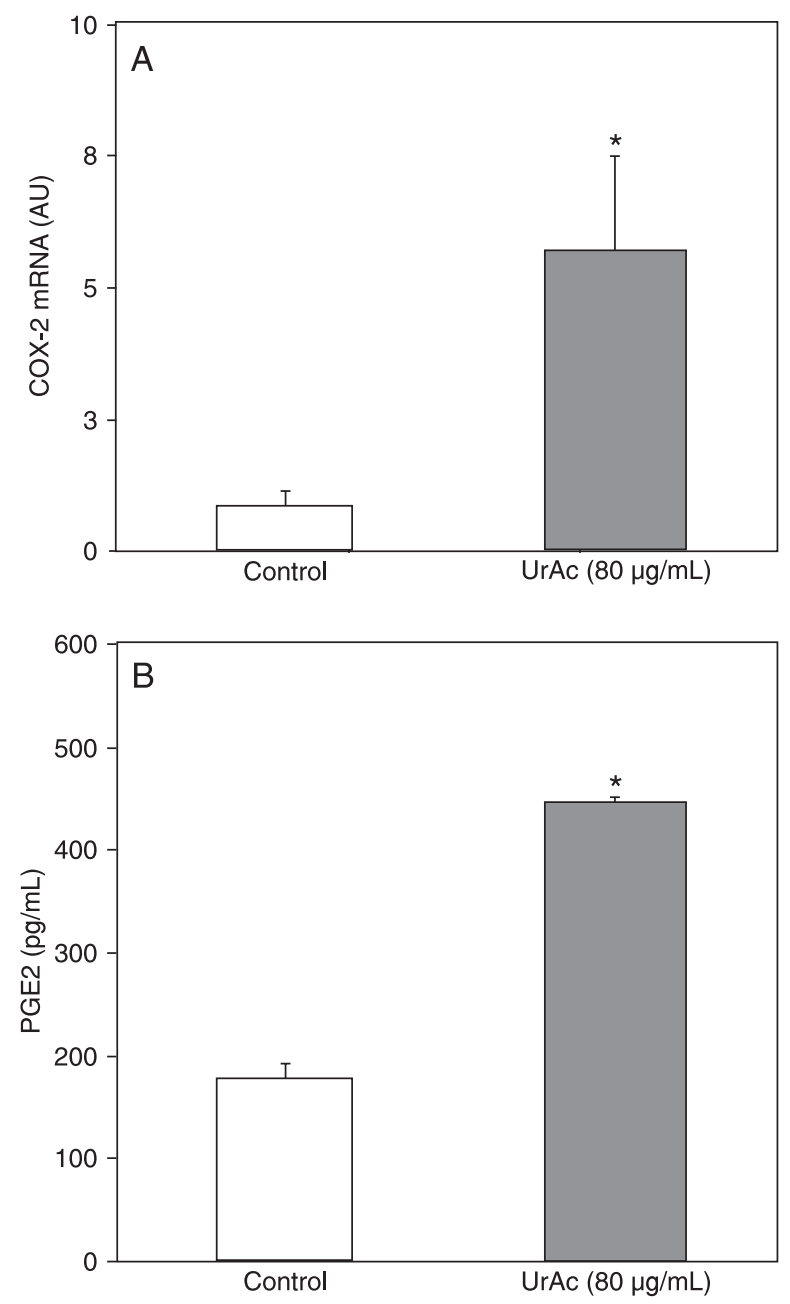

Figure 3. Effect of uric acid (UrAc) on messenger RNA (mRNA) expression of cyclooxygenase-2 (COX-2, A) and prostaglandin E2 (PGE2) production (B) in MDCK cells. A, Briefly, semiconfluent MDCK cells were treated with UrAc $(80 \mu \mathrm{g} / \mathrm{mL})$ and/ or lipopolysaccharide $(100 \mu \mathrm{g} / \mathrm{mL})$ for $24 \mathrm{~h}$. After this period, total RNA was purified and reverse transcribed into CDNA. PCR was performed with primers selective for COX-2. Real-time PCR product accumulation was monitored using the intercalating dye, SYBR Green I. The reactions were cycled 40 times under the conditions described in the text. Fluorescence for each cycle was quantitatively analyzed and relative gene expression was calculated. $B$, The concentrations of PGE2 were assessed with commercial competitive ELISAs and all assays were performed according to manufacturer protocols. Results of 8 experiments per group are reported as means \pm SEM arbitrary units (AU) for $\mathrm{PCR}$ and picograms of PGE2 per milliliter for the ELISA assay. ${ }^{*} \mathrm{P}$ $<0.05$ compared to control (Student $t$-test). 
renal stones, not only UrAc but also $\mathrm{CaOx}$ stones. Two theories have been proposed to explain this effect (26). The first proposes that urinary urate crystals could promote CaOx precipitation (27), and the second hypothesis is that urate reduces the inhibitory activity of urinary GAGs, which normally prevent $\mathrm{CaOx}$ crystallization (28).

The present study shows that noncrystalline UrAc significantly decreases the synthesis and secretion into the culture medium of CS and HS by MDCK cells. Although GAGs present in human urine are CS and HS (8), possibly of systemic origin (10), the decrease in GAGs induced by noncrystalline UrAc in MDCK cells could inhibit the interaction between $\mathrm{CaOx}$ crystal and tubular epithelial cells, consequently favoring $\mathrm{CaOx}$ aggregation or nucleation.

Additionally, noncrystalline UrAc decreased the synthesis of CS, but not the expression of versican in MDCK cells. Perhaps other CS-PG, such as biglycan and bamacan also expressed by this cell (21), could be decreased by noncrystalline UrAc stimulation. Also, high concentrations of UrAc (above, $200 \mu \mathrm{g} / \mathrm{mL}$ ) did not decrease the synthesis of CS and HS proteoglycans, but high concentrations are not observed in clinical practice, suggesting that the effect observed in the present study was specific.

An additional factor leading to the formation of UrAc or mixed uric acid/calcium salt stones is membrane injury (29). Damage to the cells lining the renal tubules may play an active role in creating the conditions for stone development. In the present study, we did not observe any injuries induced by UrAc $(80 \mu \mathrm{g} / \mathrm{mL})$ in MDCK cells. UrAc induced significant necrosis and apoptosis only at very high concentrations $(500 \mu \mathrm{g} / \mathrm{mL})$ (data not shown).

It is becoming clear that noncrystalline UrAc has a direct

\section{References}

1. Herring LC. Observations on the analysis of ten thousand urinary calculi. J Urol 1962; 88: 545-562.

2. Daudon M, Donsimoni R, Hennequin C, Fellahi S, Le Moel G, Paris M, et al. Sex- and age-related composition of 10,617 calculi analyzed by infrared spectroscopy. Urol Res 1995; 23: 319-326.

3. Mandel NS, Mandel GS. Urinary tract stone disease in the United States veteran population. I. Geographical frequency of occurrence. J Urol 1989; 142: 1513-1515.

4. Yu TF. Nephrolithiasis in patients with gout. Postgrad Med 1978; 63: 164-170.

5. Moe OW, Abate N, Sakhaee K. Pathophysiology of uric acid nephrolithiasis. Endocrinol Metab Clin North Am 2002; 31: 895-914.

6. Daudon M, Hennequin C, Bader C, Jungers P, Lacour B, Druecke T. Inhibitors of crystallization. Adv Nephrol Necker Hosp 1995; 24: 167-216.

7. Coe FI, Parks JH, Nakagawa Y. Protein inhibitors of crystallization. Semin Nephrol 1991; 11: 98-109.

8. Michelacci YM, Glashan RQ, Schor N. Urinary excretion of glycosaminoglycans in normal and stone forming subjects. pro-inflammatory effect $(30,31)$. It was shown that UrAc stimulates COX-2 expression and activation and prostaglandin synthesis (18). In the present study, we observed that UrAc crystals induced COX-2 expression and PGE2 production (19). Nevertheless, the effect of UrAc on the synthesis of GAGs and proteoglycans could not be related to its inflammatory actions, since LPS, a well known inflammatory agent, did not decrease GAG synthesis.

Urate could affect the growth, aggregation and nucleation of $\mathrm{CaOx}$ crystals (28). We determined if UrAc and the decrease of GAG synthesis could affect the endocytosis of $\mathrm{CaOx}$ crystals. There was a small, but significant decrease in $\mathrm{CaOx}$ endocytosis in the presence of UrAc. This decrease in $\mathrm{CaOx}$ endocytosis could contribute to the aggregation or nucleation of $\mathrm{CaOx}$ crystals in urine. Farell et al. (18) also analyzed the endocytosis of monohydrate $\mathrm{CaOx}$ (COM) crystals in MDCK cells exposed to UrAc. There was a significant increase in COM crystals induced by soluble or crystalline UrAc, but the study involved higher concentrations of UrAc $(500 \mu \mathrm{g} / \mathrm{mL})$ and COM $(200 \mu \mathrm{g} / \mathrm{mL})$ than used in the present study.

Taken together, our results demonstrate that UrAc has proinflammatory effects, increasing COX-2 and PGE2 production, but decreases the synthesis of GAGs and perlecan by MDCK cells. They strongly suggests that UrAc could be implicated in renal disease progression, even at the mild levels of hyperuricemia frequently observed in many diseases.

\section{Acknowledgments}

Research supported by CNPq, FINEP, Fundação Oswaldo Ramos (FOR), FAPESP, and CAPES.
Kidney Int 1989; 36: 1022-1028.

9. Angell $\mathrm{AH}$, Resnick Ml. Surface interaction between glycosaminoglycans and calcium oxalate. J Urol 1989; 141: 1255-1258.

10. Pereira DA, Aguiar JA, Hagiwara MK, Michelacci YM. Changes in cat urinary glycosaminoglycans with age and in feline urologic syndrome. Biochim Biophys Acta 2004; 1672: 1-11.

11. Groffen AJ, Veerkamp JH, Monnens LA, van den Heuvel LP. Recent insights into the structure and functions of heparan sulfate proteoglycans in the human glomerular basement membrane. Nephrol Dial Transplant 1999; 14: 2119-2129.

12. Schaefer L, Grone HJ, Raslik I, Robenek H, Ugorcakova J, Budny S, et al. Small proteoglycans of normal adult human kidney: distinct expression patterns of decorin, biglycan, fibromodulin, and lumican. Kidney Int 2000; 58: 1557-1568.

13. Michelacci YM, Cadaval RA, Rovigatti RM, Kohlman O. Renal and urinary glycosaminoglycans in an experimental model of chronic renal failure in rats. Exp Nephrol 2001; 9: 40-48.

14. Cadaval RA, Kohlman O, Michelacci YM. Urinary excretion 
of glycosaminoglycans and albumin in experimental diabetes mellitus. Glycobiology 2000; 10: 185-192.

15. Eguchi $Y$, Inoue M, lida S, Matsuoka K, Noda S. Heparan sulfate (HS)/heparan sulfate proteoglycan (HSPG) and bikunin are up-regulated during calcium oxalate nephrolithiasis in rat kidney. Kurume Med J 2002; 49: 99-107.

16. Chikama S, lida S, Inoue M, Kawagoe N, Tomiyasu K, Matsuoka K, et al. Role of heparan sulfate proteoglycan (syndecan-1) on the renal epithelial cells during calcium oxalate monohydrate crystal attachment. Kurume Med J 2002; 49: 201-210.

17. Erickson AC, Couchman JR. Basement membrane and interstitial proteoglycans produced by MDCK cells correspond to those expressed in the kidney cortex. Matrix Biol 2001; 19: 769-778.

18. Farell G, Huang E, Kim SY, Horstkorte R, Lieske JC. Modulation of proliferating renal epithelial cell affinity for calcium oxalate monohydrate crystals. J Am Soc Nephrol 2004; 15: 3052-3062.

19. Han HJ, Lim MJ, Lee YJ, Lee JH, Yang IS, Taub M. Uric acid inhibits renal proximal tubule cell proliferation via at least two signaling pathways involving PKC, MAPK, CPLA2, and NF-kappaB. Am J Physiol Renal Physiol 2007; 292: F373F381.

20. Borges FT, Michelacci YM, Aguiar JA, Dalboni MA, Garofalo AS, Schor N. Characterization of glycosaminoglycans in tubular epithelial cells: calcium oxalate and oxalate ions effects. Kidney Int 2005; 68: 1630-1642.

21. Pinhal MA, Silva IF, Lee TC, Dietrich CP, Nader HB. Binding of heparin and compound $Y$ to endothelial cells stimulates the synthesis of an antithrombotic heparan sulfate proteoglycan. Braz J Med Biol Res 1994; 27: 2191-2195.

22. Dietrich CP, Dietrich SM. Electrophoretic behaviour of acidic mucopolysaccharides in diamine buffers. Anal Biochem 1976; 70: 645-647.

23. Soriano ES, Campos MS, Michelacci YM. Effect of epithelial debridement on glycosaminoglycan synthesis by human corneal explants. Clin Chim Acta 2000; 295: 41-62.

24. Hadad SJ, Michelacci YM, Schor N. Proteoglycans and glycosaminoglycans synthesized in vitro by mesangial cells from normal and diabetic rats. Biochim Biophys Acta 1996; 1290: $18-28$.

25. Livak KJ, Schmittgen TD. Analysis of relative gene expression data using real-time quantitative PCR and the 2(-Delta Delta C(T)) Method. Methods 2001; 25: 402-408.

26. Grover PK, Ryall RL. Urate and calcium oxalate stones: from repute to rhetoric to reality. Miner Electrolyte Metab 1994; 20: 361-370.

27. Sakhaee K, Adams-Huet B, Moe OW, Pak CY. Pathophysiologic basis for normouricosuric uric acid nephrolithiasis. Kidney Int 2002; 62: 971-979.

28. Grases F, Sanchis P, Isern B, Perello J, Costa-Bauza A. Uric acid as inducer of calcium oxalate crystal development. Scand J Urol Nephrol 2007; 41: 26-31.

29. Khan SR. Calcium oxalate crystal interaction with renal tubular epithelium, mechanism of crystal adhesion and its impact on stone development. Urol Res 1995; 23: 71-79.

30. Kang DH, Park SK, Lee IK, Johnson RJ. Uric acid-induced C-reactive protein expression: implication on cell proliferation and nitric oxide production of human vascular cells. $J$ Am Soc Nephrol 2005; 16: 3553-3562.

31. Rao GN, Corson MA, Berk BC. Uric acid stimulates vascular smooth muscle cell proliferation by increasing plateletderived growth factor A-chain expression. J Biol Chem 1991; 266: 8604-8608. 